\title{
MENYAMA BRAYA DALAM PANDANGAN UPANISAD
}

\author{
Komang Fatmawati \\ Universitas Hindu Negeri I Gusti Bagus Sugriwa Denpasar \\ email : komangfatmawati23@gmail.com
}

Diterima: 24 Maret 2021, Direvisi : 18 April 2021, Diterbitkan : 27 April 2021

\begin{abstract}
This paper aims to convey an understanding of Brama Brama in the view of Upanishad. Upanisad is a book that cannot be separated from the Vedic scriptures. Even each part of the Chess Weda Samhita each has an Upanishad, albeit with different amounts. There are so many teachings contained in the Upanishads, one of which is the teachings on norms that teach about harmonization of life both human and human, human beings with God, and humans with the natural surroundings. Humans other than as individual beings are also at the same time as social beings where humans need interaction with other humans in order to meet their needs. Tri Hita Karana which in its division is Pawongan which means a harmonious relationship between humans and humans. The interactions that occur in Balinese Hindus are not only the application of the teachings of Tri Hita Karana but also as the application of the teachings of Tat Tvam Asi.
\end{abstract}

\section{Keywords : Menyama Braya, Upanisad}

\section{PENDAHULUAN}

Masyarakat Hindu Bali dari jaman dulu telah mengenal istilah Menyama Braya. Menyama Braya merupakan istilah yang sering didengar saat melakukan upacara yadnya dimana pada saat melakukan upacara yadnya masyarakat saling bahu membahu demi kelancaran upacara yadnya yang dilakukan.

Istilah menyama braya berasal dari dua kata, yakni "nyama" dan "braya". Kata Nyama mendapat awalan "me" menjadi "menyama" yang berarti saudara. Sedangkan kata "braya" memiliki arti tetangga terdekat, orang sekitar atau semua umat manusia karena satu jalan kelahiran (horizontal). Menyama braya merupakan istilah yang memiliki arti bahwa semua manusia adalah bersaudara atau cara hidup yang memperlakukan orang lain seperti saudara sendiri (Wisnumurti, 2010). Tulisan ini berupaya untuk memberikan kontribusi pemahaman mengenai Menyama Braya dalam pandangan Upanisad. Terdapat banyak ajaran-ajaran agama hindu yang memuat mengenai hubungan manusia dengan manusia. Salah satunya adalah Tri Hita Karana. Umat Hindu sebagai masyarakat sosial, dalam kehidupan sehari-harinya juga memiliki konsep yang mengatur pola kehidupan yang dikenal dengan istilah Tri Hita Karana.

Menurut I Ketut Wiana ( 2004 : 141) menekankan tiga hubungan manusia dalam kehidupan di dunia ini. Ketiga hubungan itu meliputi hubungan dengan sesama manusia, hubungan dengan alam sekeliling, dan hubungan dengan ke Tuhan-an yang saling terkait satu sama lain. Setiap hubungan yang dilakukan oleh umat manusia memiliki pedoman hidup menghargai sesama aspek sekelilingnya. Dalam pengimplementasian konsep Tri Hita Karana, sangat ditekankan bahwa ketiga unsurnya harus diaplikasikan secara utuh. Unsur parahyangan, 
pawongan, dan palemahan memiliki kedudukan yang sama tidak ada yang diistimewakan atau diutamakan.

Konsep dasar Tri Hita Karana tersebut dan bila dikaji dari artinya pembagiannya sebagaimana tergambarkan diatas maka konsep berupa :

- Parahyangan adalah hubungan yang harmonis antara manusia dengan Tuhan (Ida Sang Hyang Widhi Wasa),

- Pawongan adalah hubungan yang harmonis antara manusia dengan sesamanya,

- Palemahan adalah hubungan yang harmonis antara manusia dengan lingkungannya (Subagia, 2016).

Dalam unsur pawongan yang memiliki arti hubungan yang harmonis antara manusia dengan manusia di Bali dapat kita lihat secara jelas pada saat upacara yadnya baik sebelum bahkan sampai upacara yadya tersebut selesai dilaksanakan. Pada saat persiapan upacara yadnya biasanya masyarakat Hindu Bali akan saling tolong menolong baik dalam mencari bahan-bahan upacara, mejejaitan bagi yang perempuan bahkan gotong royong membersihkan area pura bagi yang laki-laki. Semua kegiatan yang dilakukan demi kelangsungan upacara yadnya.

\section{METODE}

Tulisan ini menggunakan metode kualitatif berbentuk narasi deksriptif. Bogdam dan Taylor (1975:5) dalam Meleong (2010:4) mendeskripsikan metodologi kualitatif sebagai prosedur penelitian yang menghasilkan data deskriptif berupa kata-kata tertulis atau lisan dari orangorang dan prilaku yang diamati. Penelitian ini berbentuk narasi yang berarti menjelaskan suatu peristiwa atau kejadian dalam bentuk tulisan yang memiliki rangkaian peritiwa yang dijabarkan secara berurutan dari awal, tengah dan akhir yang bertujuan membuat pencanderaan/ lukisan/ deskripsi mengenai fakta dan sifat suatu populasi atau daerah tertentu secara sistematik, faktual dan teliti, serta meluas dari beberapa veriabel. Pembahasan dalam Bab selanjutnya meliputi penjelasan mengenai manusia sebagai makhluk sosial dalam pandangan Agama Hindu dan Menyama Braya dalam pandangan Upanisad

\section{HASIL DAN PEMBAHASAN}

Menurut Inah (2013: 177), manusia secara pribadi maupun sebagai makhluk sosial ingin memenuhi kebutuhan secara umum, yaitu kebutuhan ekonomis, kebutuhan biologis dan lain sebagainya. Untuk memenuhi kebutuhan ini manusia tidak dapat berdiri sendiri, ia harus bekerja sama dengan orang lain atau masyarakat. Tanpa mengadakan kerja sama dan hubungan keutuhan tersebut tidak akan dapat terpenuhi, oleh sebab itu manusia baik secara pribadi maupun secara bersama saling memerlukan dan saling melakukan hubungan.

\subsection{Manusia Makhluk Sosial dalam Pandangan Agama Hindu}

Masyarakat Bali sudah terbiasa dengan melakukan gotong royong. Hal ini merupakan salah satu implementasi ajaran pawongan. Selain gotong-royong, masyarakat Bali juga terbiasa untuk saling bahu membahu apa bila terdapat anggota masyarakat yang melakukan upacara manusia yadnya. Bahu membahu dalam melaksanakan upacara yadnya ini juga sebagai aplikasi dari ajaran Tat Tvam Asi. Kata "Tat Tvam Asi" dijelaskan dalam kitab Candogya Upanisad yang memiliki arti: Dikaulah itu; Dikaulah semua itu; Semua makhluk adalah Engkau. Engkau awal mula jiwatman (roh) dan zat (prakrti) semua makhluk. Aku ini adalah makhluk yang berasal dari Mu. Oleh karena itu jiwatmaku dan prakrtiku tunggal dengan jiwatman semua makhluk, dan Dikau sebagai sumberku dan sumber semua makhluk. Oleh karena itu aku adalah Brahma." Aham Brahma Asmi" (Brhadaranyaka Upanisad 1.4.10).

Kalimat Tat Tvam Asi menjelaskan bahwa sesama makhluk hidup harus saling menyayangi sebagai sesama makhluk ciptaan Tuhan. Mengasihi orang lain seperti mengasihi 
diri kita sendiri. Dalam kitab suci dikatakan demikian :"Hyang amati-mati wang tan padosa, haywa anglarani sarwa prani, haywa kita tan masih ring wang nista" Artinya: Janganlah menyakiti makhluk hidup, janganlah tidak menaruh belas kasihan terhadap orang miskin atau orang yang ditimpa kemalangan. Cinta kasih sejati ditandai dengan cinta kepada kebenaran dan kebaikan, maka menjadi kewaijban setiap orang untuk berbuat baik dan benar (Suciartini: 125).

Dalam kitab Yajur Weda, 40.70 menyebutkan bahwa: "orang yang menganggap seluruh umat manusia memiliki Atman yang sama dan dapat melihat semua manusia sebagai saudaranya, orang tersebut tidak terikat dalam ikatan dan bebas dari kesedihan". Dari sloka diatas dijelaskan bahwa umat Hindu hendaknya memandang semua umat manusia itu sama dikarenakan atma yang ada dalam diri manusia itu sama, sama-sama berasal dari Brahman.

Dari kedua konsep yang mengatur tentang pola kehidupan masyarakat Hindu Bali sangat jelas bahwa semua makhluk merupakan saudara yang harus dikasihi, disayangi layaknya mengasihi dan menyayangi diri sendiri. Dijelaskan pula bahwa adanya cinta kasih kepada semua makhluk sesungguhnya bukan ditujukan kepada fisiknya tetapi kepada Atmannya. Percakapan Yajnavalkya dan Maitreyi memberikan pendidikan cinta kasih kepada semua pihak untuk mewujudkan kehidupan yang harmonis di alam ini dan juga sesudahnya. Dengan demikian pada percakapan ini pada hakikatnya berintikan kemutlakan dan keuniversalan sifat atman. Hanya atman yang masih tetap ada setelah badan jasmani ini lenyap. (Sutrisna, 2009;83)

\subsection{Menyama Braya dalam Pandangan Upanisad}

Menyama Braya merupakan kekayaan yang sangat diperlukan demi keharmonisan hidup umat bermasyarakat. Tidak hanya sesama etnis maupun agama tetapi pada siapa pun tanpa memandang etnis, agama, ras bahkan warna kulit.

Istilah menyama braya berasal dari dua kata, yakni "nyama" dan "braya". Kata Nyama mendapat awalan "me" menjadi "menyama" yang berarti saudara. Sedangkan kata "braya" memiliki arti tetangga terdekat, orang sekitar atau semua umat manusia karena satu jalan kelahiran (horizontal). Menyama braya merupakan istilah yang memiliki arti bahwa semua manusia adalah bersaudara atau cara hidup yang memperlakukan orang lain seperti saudara sendiri (Wisnumurti, 2010).

Bentuk menyema braya di bali dapat kita lihat dari gotongroyong pada saat terdapat upacara baik itu upacara dewa yadnya maupun manusia yadnya. Selain itu menyama braya juga dapat dilihat dari umat Hindu yang saling membesuk apabila terdapat saudara maupun tetangga yang sedang sakit. Dari membesuk inilah umat Hindu mencerminkan ajaran Tat Tvam Asi.

Tuhan merupakan sari pati yang paling halus menghuni tubuh manusia yang merupakan sumber utama kehidupan, dari sari pati Tuhan ini muncul Mahavakya yang sangat terkenal, yaitu Tat tvam asi.

Pada hakikatnya, Brahman diturunkan dari akar kata "brh" yang berarti tumbuh dan yang menyebabkan tumbuh atau hidup dari segala entitas hidup dan eksistensi. Oleh karena itu, dalam kitab Upanisad, Tuhan dipandang menyusupi segalanya, sebagaimana Mahavakya (kalimat agung) dari Upanisad menyebutkan Sarvam Kaluidam Brahman yang artinya semuanya adalah Tuhan (Budiawan, 2021).

Dalam Maha Upanisad dijelaskan pula bahwa "Vasudhaiva Kutumbakam" yang berartikan seluruh dunia ini adalah satu keluarga tunggal karena berasal dari sari pati yang sama yaitu Ida Sang Hyang Widhi. Terlepas dari semua persamaan dan perbedaan yang dimiliki semuanya adalah satu keluarga. Karena seluruh dunia adalah satu keluarga tunggal, alangkah baiknya jika semua umat manusia memiliki rasa toleransi yang tinggi guna saling menghargai setiap perbedaan yang ada. Karena tidak semua kegiatan yang dilakukan akan selalu seiring sejalan. Ketidaksamaan inilah yang dapat memecah persaudaraan yang telah dimiliki jadi untuk mencegah terjadinya perpecahan adalah dengan menyadari bahwa kita 
adalah saudara, terlepas dari perbedaan yang dimiliki kita adalah satu keluarga tunggal dengan asal yang sama.

Orang yang telah memiliki pengetahuan spiritual mendalam akan benar-benar meyakini dan mampu melihat serta merasakan bahwa Tuhan ada dalam semua ciptaan, semua mahkluk adalah berasal dari sumber yang sama (Wiguna: 95). Dalam Brhadaranyaka Upanisad brahmana kelima menyebutkan bahwa "Pada mulanya dunia ini adalah Atman, dalam bentuk sebagai seseorang. Melihat ke sekelilingnya dia tidak melihat apa-apa kecuali dirinya. Pertama-tama dia berkata "Aku”. Karena itu terciptalah kata aku. Karena itu bahkan sampai sekarang, jika seseorang disebut pertama-tama ia akan berkata "inilah aku", dan kemudian menyebutkan nama apa saja yang dia punyai......". dalam sloka tersebut dapat diartikan bahwa kata "Aku" merupakan sang Brahman sedangkan kata "aku" menjelaskan ciptaannya. Jadi setiap ciptaan Ida Sang Hyang Widhi yang menyebutkan diri sebagai "aku", menandakan bahwa dalam ciptaan Ida Sang Hyang Widhi tersebut terdapat Tuhan itu sendiri. Yang dalam semua makhluk hidup disebut dengan atman. Secara sederhana dapat dijelaskan bahwa Ida Sang Hyang Widhi ada pada setiap ciptaan-Nya baik diluar maupun didalamnya. Baik diruang yang kecil maupun yang luas sekalipun.

Brhadaranyaka Upanisad Bab II brahmana keempat mantram kelima juga menyebutkan bahwa "sesungguhnya bukan untuk kepentingan sang suami, sang suami disayangi, tetapi sang suami disayangi untuk kepentingan atman. Sesungguhnya bukan untuk kepentingan sang istri, sang istri disayangi, melainkan sang istri disayangi demi kepentingan sang atma. Sesungguhnya bukan untuk kepentingan sang anak, sang anak disayangi, melainkan sang anak disayangi demi kepentingan sang atma. Sesungguhnya bukan untuk kepentingan kekayaan, kakayaan itu disayangi, melainkan kekayaan itu disayangi demi kepentingan sang atma. Sesungguhnya bukan untuk kepentingan kebrahmanaan, kebrahmanaan itu disayangi, melainkan kebrahmanaan itu disayangi demi kepentingan sang atma. Sesungguhnya bukan untuk kepentingan kekesatriyaan, kekesatriyaan disayangi, melainkan kekesatriyaan disayangi demi kepentingan sang atma. Sesungguhnya bukan untuk kepentingan dunia, dunia disayangi, tetapi disayangi demi kepentingan sang atma. Sesungguhnya bukan untuk kepentingan makhluk-makhluk, makhluk-makhluk disayangi tetapi demi kepentingan sang atma. Sesungguhnya bukan untuk kepentingan semuanya, semuanya disayangi tetapi demi kepentingan sang atma. Sesungguhnya Maitreyi, atman inilah seharusnya dilihat, didengar, dipikirkan,dan Samadhi kepadanya. Sesungguhnya dengan melihatnya, dengan mendengarnya, dengan memikirkannya dengan mengerti tentang atman, semuanya akan dimengerti."

Inti dari sloka tersebut adalah menyatakan bahwa yang paling utama dalam segala hal adalah atman. Atman adalah inti dari semua makhluk hidup. Hal ini perlu direnungkan oleh semua orang bila orang orang tersebut telah mencapai kesadaran mengenai pentingnya atman, orang tersebut akan mengetahui semua rahasia tentang alam semesta ini.

Kamajaya (2001:xxviii) dalam pengantar terjemahan Vedanta dalam karya Svami Vivekananda (dalam jurnal Wiguna: 95 ) menyatakan bahwa Ramakrsna Paramahamsa adalah tokoh spiritual yang ideal. Disatu pihak ia memuja Tuhan dengan segala cintanya, tetapi disatu sisi pengenalan dirinya sebagai Atman membuat ia mengenali bahwa ia satu dengan semua makhluk, dan satu dengan Tuhan yang ia puja. Kitab Veda menyimpulkan semua itu dengan ucapan agungnya (mahavakya).

Cinta kasih yang diberikan kepada semua makhluk hidup sesungguhnya bukan ditujukan kepada badan atau fisiknya tetapi kepada Atman yang bersemayam pada diri makhluk tersebut. Sloka ini memberikan pendidikan cinta kasih kepada semua makhluk untuk mewujudkan kehidupan yang harmonis. Dengan demikian pada percakapan ini pada hakikatnya berintikan kemutlakan dan keuniversalan sifat atman. Hanya atman yang masih tetap ada setelah badan jasmani ini lenyap (Sutrisna, 2009:83). 
Paul Deussen sebagaimana ditulis oleh Juan Mascaro mengatakan bahwa doktrin Upanisad ini mendahului dan menjelaskan doktrin Gospel "Engkau hendaknya mencintai tetanggamu seperti mencintai dirimu sendiri". Atman kita, Sang Diri kita yang lebih tinggi, berdiam di dalam diri kita dan tinggal di dalam diri tetangga kita. Bila kita mencintai tetangga kita, kita mencintai Tuhan yang ada di dalam diri kita. Kita mencintai Tuhan yang ada dalam diri kita semua dan di dalam mana kita semua hidup, dan bila kita menyakiti tetangga kita, dalam pikiran atau kata-kata dan tindakan, kita menyakiti diri kita sendiri, kita menyakiti jiwa kita, inilah yang disebut hukum gravitasi spiritual (Wiguna: 95).

Dari sloka yang telah dijelaskan diatas Menyama braya merupakan sebuah pengaplikasian dari ajaran-ajaran suci yang dimiliki oleh umat hindu dari jaman dahulu. Sebuah konsep kebersamaan, asah, asih dan asuh. Ajaran-ajaran yang dimiliki oleh umat hindu sejatinya tidak hanya sebatas diaplikasikan kepada sesama umat hindu saja tetapi kepada semua makhluk yang ada terlepas dari semua perbedaanya. Saling bahu membahu karena pada dasarnya manusia tidak bisa hidup sendiri. Manusia juga merupakan makhluk sosial yang membutuhkan bantuan orang lain untuk memenuhi kebutuhannya.

\section{KESIMPULAN}

Kerukunan umat Hindu di Bali sebenarnya sudah terjaga melalui menyama braya. Menyama braya diartikan sebagai sebuah interaksi sosial yang menghargai perbedaan baik dari suku, agama dan bahasa. Yang mana menyama braya ini merupakan pengaplikasian dari ajaran-ajaran yang diajarkan dalam upanisad yang disebutkan dalam mahavakya upanisad.

Pemahaman manusia hidup dengan saling memahami bahwa semua makhluk hidup adalah bersaudara atau cara hidup yang memperlakukan orang lain seperti saudara sendiri, selanjutnya dimaknai sebagai bentuk toleransi atau kebersamaan masyarakat yang multi budaya, multi etnis dan multi agama yang dalam hal ini dapat terwujud dalam bentuk Tat Tvam Asi dan Tri Hita Karana.

Melalui ajaran Upanisad agama Hindu telah membawa pemikiran menuju puncak pemahaman realitas dimana Tuhan dalam Upanisad dipahami dan diyakini bersemayam didalam setiap makhluk, setiap benda di alam semesta serta berada jauh di luar jangkauan pemikiran manusia.

Inti ajaran upanisad dapat dimaknai sebagai jalan pelayanan. Melayani sesama makhluk ciptaan Tuhan dimana didalam setiap makhluk didunia ini memiliki sari pati dari Brahman sendiri. Melayani ciptaan-Nya memiliki arti yang sama dengan melayani Tuhan itu sendiri.

\section{Daftar Pustaka}

Budiawan, Ketut. 2021. Pentingnya Penguatan Literasi Beragama Umat Hindu. Https://Kemenag.Go.Id/Read/Pentingnya-Penguatan-Literasi-Beragama-Umat-HinduGm93o (Diakses Tanggal 17 April 2021)

Inah, Ety Nur, 2013. Peranan Komunikasi Dalam Pendidikan. Jurnal. Stain Sultan Qaimuddin Kendari

Meleong. 2010. Metodologi Penelitian Kualitatif. Bandung. Pt Remaja Rosdakarya

Subagia, Ni Komang Wisesa. 2016. Persepsi Masyarakat Terhadap Konsep Tri Hita Karana

Sebagai Implementasi Hukum Alam. Jurnal. Universitas Lampung Bandar Lampung

Suciartini, Ni Nyoman Ayu. Prinsip Tat Tvam Asi Dalam Pendidikan Hindu Guna Mencegah

Prilaku Verbal Bullying. Jurnal. Institut Hindu Dharma Negeri Denpasar

Sutrisna, I Made. 2009. Modul Pokok Upanisad. Jakarta. Direktorat Jenderal Bimbingan Masyarakat Hindu Departemen Agama Ri

Wiana, Ketut. 2007. Tri Hita Karana Menurut Konsep Surabaya. Paramita. 
Wiguna, I. M. A. (2017). Memaknai Mahavakya Sebagai Bentuk Universalitas Veda Dalam Upaya Membangun Semangat Kebhinekaan. In Prosiding Seminar Pendidikan Agama (pp. 93-102).

Wisnumurti, O.W. 2010. Mengelola Nilai Kearifan Lokal Dalam Mewujudkan Kerukunan Umat Beragama (Suatu Tinjauan Empiris-Sosiologis). Diakses Dari Http://Www.Yayasan Korpribali.Org/Artikel-Dan-Berita/59-Mengelola-Nilai-KearifanLokal-Dalam-Mewujudkan-Kerukunan-Umat-Beragama.Html Pada Tanggal 6 Januari 2019. 